\title{
Factors impeding political participation and representation of women in Kenya
}

\author{
Douglas Lucas Kivoi \\ Kenya Institute for Public Policy Research and Analysis (KIPPRA), Governance Division, Nairobi, Kenya
}

Email address:

amatalo2000@yahoo.com,dkivoi@kippra.or.ke

\section{To cite this article:}

Douglas Lucas Kivoi. Factors Impeding Political Participation and Representation of Women in Kenya. Humanities and Social Sciences. Vol. 2, No. 6, 2014, pp. 173-181. doi: 10.11648/j.hss.20140206.15

\begin{abstract}
The quest for gender equity in Kenya is relevant for effective gender mainstreaming. Women have been marginalized and underrepresented in organs of decision-making and in governance structures of the country since independence. Kenya's Constitution offers a framework to address this historical marginalization. Even though a number of women have made great strides in politics in the country, women representation is far below the minimum one third public service requirement of Article 27(3) of the Constitution of Kenya. Traditional beliefs, perceptions and stereotypes which depict women as being inferior have tended to militate towards their marginalization. Data on the numbers of elected Parliamentarians (including Senators, Governors and County Representatives) and holders of senior government positions shows that gender equity is still a mirage. Cultural impediments to women's economic emancipation have also denied them political representation in the Legislature. Kenya has the challenge of identifying and implementing mechanisms - policies and practices - so as to achieve gender equity. Political parties are not keen to try and implement the minimum one third constitutional requirement for their lists of candidates nominated to vie in elections. Advancing the participation of women in devolved governance structures requires serious consideration by putting in place policy measures and interventions that would further this cause since equal gender participation is enshrined in the Constitution. It appears lack of political will is the biggest obstacle in addressing gender imbalance in the country. Thus there is greater need to address gender inequality in political representation and decision making in the country.
\end{abstract}

Keywords: Gender, Equity, Mainstreaming, Marginalized, Stereotypes, Cultural Impediments, Emancipation

\section{Introduction}

Gender equality was first declared a development agenda in the United Nations Charter of 1945, and was subsequently addressed in the Universal Declaration of Human Rights (1948) and the Millennium Development Goals (MDG's) of 2000. Kenya is also a signatory to other international treaties on women empowerment, key among them being the African Union's Solemn Declaration on Gender Equality in Africa (2004), the Protocol to the African Charter on Human and Peoples' Rights on the Rights of Women in Africa (2003), the African Plan of Action to Accelerate the Implementation of the Dakar and Beijing Platforms for Action for the Advancement of Women (1999) and the Constitutive Act of the African Union, the Dakar Platform for Action (1994). International fora, including the Cairo Conference on Population and Development in 1994, Fourth World Conference on Women of 1995, and World Summit for Social Development of 1995, affirmed that inequalities still persist in women's political representation despite the progress made globally in improving their status. Despite the establishment of a national task force on gender and education in 1995, a national policy on gender and education was not formulated until 2008 (Republic of Kenya 2007). The policy provided a framework for planning and implementation of gender responsive education, as well as research and training. However it suffered numerous setbacks key among them being the infamous $2007 / 2008$ post-election violence that led to loss of lives and destruction of property characterized by wanton human rights violations especially rape.

Despite subscribing to international commitments to empower women, Kenya still lags behind in terms of women representation in politics and decision making in East African region. Political participation is the degree and forms of involvement of citizens in governance and related institutions of society, such as the economy and culture (Igwee 2002). It thus involves participation in political campaigns and debates, attending strategy meetings of political parties, voting during 
elections, vying as candidates for elections, and holding of key government and political party positions. Equal political participation of both genders is one of the critical pillars of good governance which entails freedom of expression, freedom of association among other fundamental rights.

The third Millennium Development Goal (MDG), categorically states that by 2015 all countries, Kenya included, need to eliminate gender disparities in all levels of education and labor relations. On this note the Constitution of Kenya, guarantees equal rights and freedom for women and men, and upholds the principles of non-discrimination and equality. Articles 27(8) and (81) (b) of the Constitution provides for no more than two thirds representation of one gender in elective and appointive positions as a way of bridging the gender gap.

The participation of women in decision-making and politics is a human rights issue enshrined in the Constitution, which has tried to address many issues that have been at the heart of the clamor for gender mainstreaming in Kenya from the 1980s. Given their underrepresentation in the Legislature and other state decision making organs, women have not been involved in such reviews, meaning that their interests were not articulated. The Constitution has addressed this shortcoming in Article 100 by empowering the National Parliament to enact legislations that will promote the representation of women, youth and other vulnerable groups that have been historically marginalized since independence. Cultural, religious and social norms in most communities in Kenya impede equal gender representation in political governance underscoring the need for a multi-pronged approach to ensure the attainment of the third MDG.

Thus the exclusion of women from political and other decision making structures in Kenya is a result of many multiple structural and functional factors that vary in different social contexts across the newly established 47 Counties. It appears the society as a whole has not yet acknowledged women's leadership rights and abilities. When the National Rainbow coalition (NARC) government was elected in 2003, it established the Gender Commission and an autonomous Ministry of Gender. The National Policy on Gender and Development of 2000 provided a framework with which the government could address gender imbalances strategically through established legal and institutional frameworks towards women empowerment.

\section{The Issue at Hand}

The Kenyan Constitution in Articles 27(8) and (81) (b) promises to increase space for women's representation and provides for a minimum of one third of either gender representation in all elective and public appointments. Kenya's male-dominated Senate and National Assembly chambers have not passed any legislation to put this constitutional principle into practice despite article 27(6) of the Constitution requiring the State to enact legislations that will redress historical discriminations and injustices (Okello, 2010).

Though Kenya is the leading economy in East Africa, it still lags behind in gender representation in political participation and decision making. In the 2012 Gender Inequality index, Kenya was ranked at position 145 out of 186 countries according to the Human Development Report 2013. Available data indicate that gender inequity is still prevalent in the country (Ouma \& Maina 2010). Lack of political will is partly to blame for the 10th Parliament's failure to legislate constitutional guarantees of affirmative action (Nyanjom 2011). It should also be noted that as currently constituted the National Assembly, Senate and County Governments do not meet the minimum one third gender constitutional representation requirement. The purpose of this research is to find out factors that impede participation of women in political governance and decision making in Kenya and come up with policy recommendations that can be used to reverse the context.

\section{Justification of the Study}

The key contribution of this study is to stimulate policy reorientation towards increased gender mainstreaming. This research is also relevant for policy measures on gender mainstreaming and recommends creation of public awareness to the electorate on the importance of equal gender representation in the country. The research is timely since political participation and representation of women is yet to reach the minimum one third constitutional requirement. It is hoped that this research will lead to further policy measures that will inform legislation to enhance the representation of women in political governance and gender mainstreaming as envisaged in the Constitution which advocates for equal gender participation and representation.

\section{Literature Review}

The low participation and representation of women in public and political institutions of the country like the Senate, National Assembly and County Assemblies negates the equity that is affirmed in the constitution. Kenya acceded to the gender equality platform in the context of its commitments to various United Nations (UN) resolutions, such as the Universal Declaration of Human Rights and Convention for the Elimination of Violence Against Women (CEDAW) (Nyanjom 2011). It also espoused the 1966 covenants on Civil, Political, Economic, Social and Cultural Rights. In 1985, the country was at the center of gender equality initiatives when it hosted the formulation of the Nairobi Forward Looking Strategies for the Advancement of Women, and was at forefront of continental preparations for the 1994 International Conference on Population and Development and the 1995 Beijing Platform for Action, a motion adopted by Parliament in 1996. However despite Kenya acceding to all these international declarations, gender mainstreaming has remained elusive. Githinji (2010) in his review of Kenya's Vision 2030 found out that persisting gender neutrality has kept women in lower paying jobs even as their share of the labor force has increased from $18 \%$ in 1966 to $30 \%$ in 2006, and a likely $55 \%$ by 2016 . It should be noted that achieving 
gender equity as stipulated in Vision 2030 will not be easy.

Karl (2001) identifies some obstacles that hinder women's participation in political affairs worldwide. They include low education and literacy levels, low access to financial resources, cultural attitudes and stereotypes, religion and socialization, among other factors. Cooper and Karl (1982) found that women face stress while at work, home and in social environments. Women are also supposed to acquire masculine leadership characteristics and management skills like aggressiveness and assertiveness among others so as to excel in their careers.

Scholars like Tremblay (1998), Devlin et al (2008) among others have argued that there is a strong link between increased presence of women in parliament and the representation of issues affecting women (women issues). Tremblay (1998) further argues that female members of parliament represent the needs, wishes and interests of female members of the populace in a country. According to Carroll (1994) policies concerning women are more likely to have more and wider direct impact on the population than those of men in a country. Among the issues include family planning, maternal health, education, Female Genital Mutilation (FGM), violence against women.

Oduol (2011) sees lack of institutional political party structures with which to enhance women's participation, which he blames for the low levels of women in politics thus their limited representation in Parliament and also within political parties. Political parties seem to be a waterloo for increased women representation since stringent party rules, violence meted against women; cultural barriers among other impediments always appear to halt increased women participation in active politics and decision making. Kenya's social cultural beliefs and practices such as patriarchy and elder veneration have most of the time worked against women empowerment. That is why Kenya's extensive commitment to various gender equality protocols have hardly narrowed the inequality gap (Nyanjom 2011).

\section{Conceptual Framework}

Gender is a socially and culturally constructed factor that is pegged on gender roles. It refers to traits social, cultural, and psychological characteristics linked to males and females through socialization. Gender is a social tool responsible for distribution of roles based on femininity and masculinity. Allocation of gender roles is reinforced through socialization which in essence gives an individual his/her identity in the social structures. Sex and gender are not the same since sex is the biological difference between male and female and gender entails roles constructed through different socialization of males and females. Gender roles keep changing and evolving with time. Gender roles have tended to favor men as a result of the patriarchal and stereotypical nature of many African societies. Political participation and representation in Kenya has always taken a sexist perspective where women only participate as voters.

Apart from roles, gender also entails aspects of power relations, privileges, rights and responsibilities. Gender theory recognizes the role of social structure in shaping gender roles in society. It is based on the perception that women have less power and status than men and control fewer means of production. This feature of social structure is a pointer to a gender hierarchy of marginalization. Feminist scholars call it patriarchy where the male gender is in total control of all means of production and decision making in the community. History scholars have indicated that men in traditional societies specialized in masculine activities such as warfare, herding among others which came with greater status, power and wealth. Women specialized in activities such as housekeeping and child-rearing, which brought loving appreciation. Thus when gender roles emerged in modern society, it favored men more and relegated women from power and authority. Structural factors that impede women's participation in political processes include the resistance of society especially by both men and women to female leadership, absence of political good will from political parties to ensure equal participation and representation of women in party affairs, and the lack of clear legal mechanisms backed by relevant policies for gender mainstreaming in the country.

Stereotype beliefs on women leadership can be traced to cultural factors which are socially constructed. While male gender roles tend to be more empowering and domineering, female gender roles seem to be less empowering and subservient in nature. These subservient gender roles and societal expectations hinder the participation of women in politics. Cultural practices and perceptions in Kenya represent major obstacles to women's participation in political governance and decision making. Practices such as early, forced, and/or arranged marriages impede women's empowerment and affirmative action in particular. Such practices, limit women's chances to advance their education which may open doors for political participation of women. Communal stereotypes, long held traditional anachronistic belief have for long viewed women as suited only for domestic chores and politics a domain for men only (Thomas 1994).

\section{Methodology}

This research on factors that impede the political participation and representation of women in Kenya was a desk research study that involved an analysis of socially constructed traits both social, cultural and psychological characteristics licked to socialization that define femininity and masculinity. This helped in conceptualizing and realigning the problem with secondary data obtained from various sources.

\section{Discussion}

Kenya's oldest women's organization is the Maendeleo ya Wanawake Organization (MYWO) which is one of the oldest women empowerment groups was founded in 1952 by white women settlers. Its main focus was centered on empowering women economically through capacity building programs 
aimed at generating income and mitigating against effects of poverty. MYWO never ventured into empowering women to take a proactive role in political participation and representation. Women were thus excluded from participating in elective politics since independence partly because MYWO did not play its role well and also because of the oppressive culture which made them believe that politics and leadership is for men only. Oldest Political parties like Kenya African National Union (KANU) recognized the power of MYWO and used its power to mobilize women to vote for its party candidates. It was thus not easy to have women oriented legislation that would punish political parties that flout the constitution and refuse to observe gender mainstreaming.

In the March 2013 elections, apart from the 47 county women representatives who were elected by virtue of them being women, only 16 constituencies out of the 290 constituencies are represented by elected women. Of the 1450 county wards contested in the 47 counties, only 88 are represented by women. Previously only 22 women sat in the former 222 seat parliament. This is a pointer to the fact that the marginalization of women that has been there in past in the centralized governance appears now to be taking shape in counties where none of the 47 County governors elected is a woman. The exclusion of women from decision-making and political representation is counterproductive for the entrenchment of the principles of democracy and gender equity.

According to the 2012 Ibrahim Index of African Governance (IIAG) indicator scores, Kenya still lags behind other sub-Saharan countries when it comes to overall as seen in Figure 1 below. IIAG measures performance in governance under four main conceptual pillars one of which is participation and human rights.

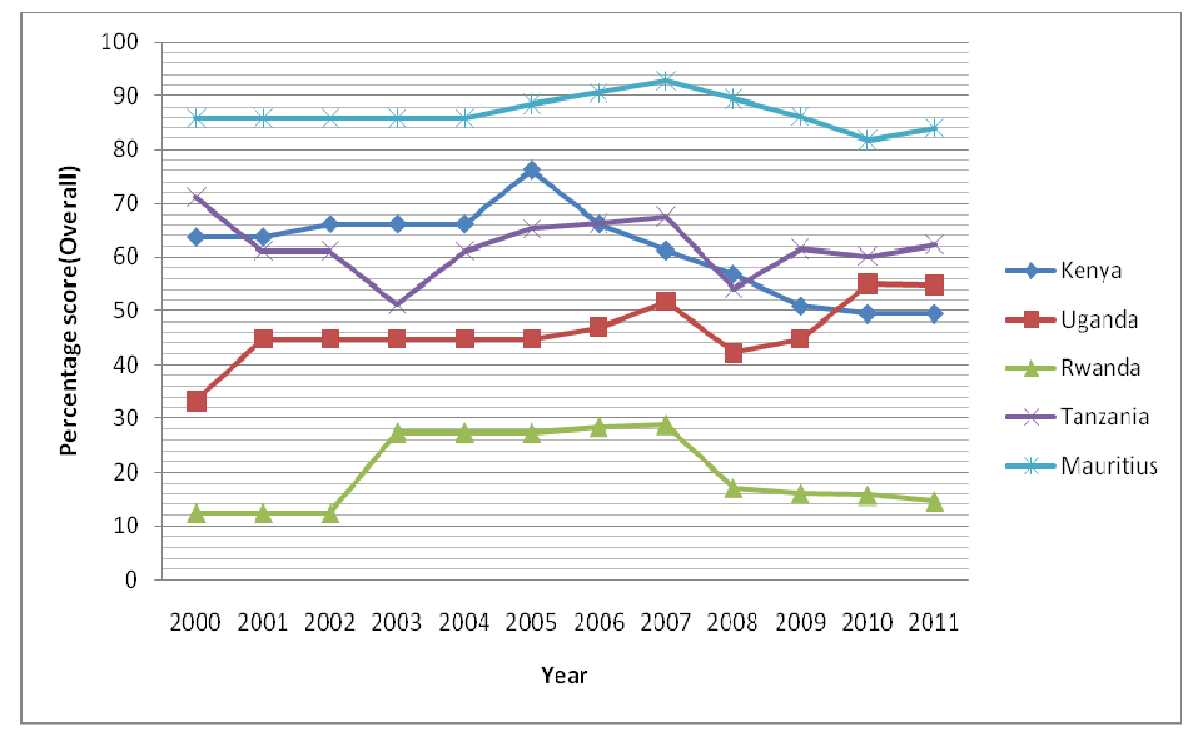

Source: Compiled by author from Molbrahim (2012)

Figure 1. Overall Political Participation in Eastern Africa (2000-2011)

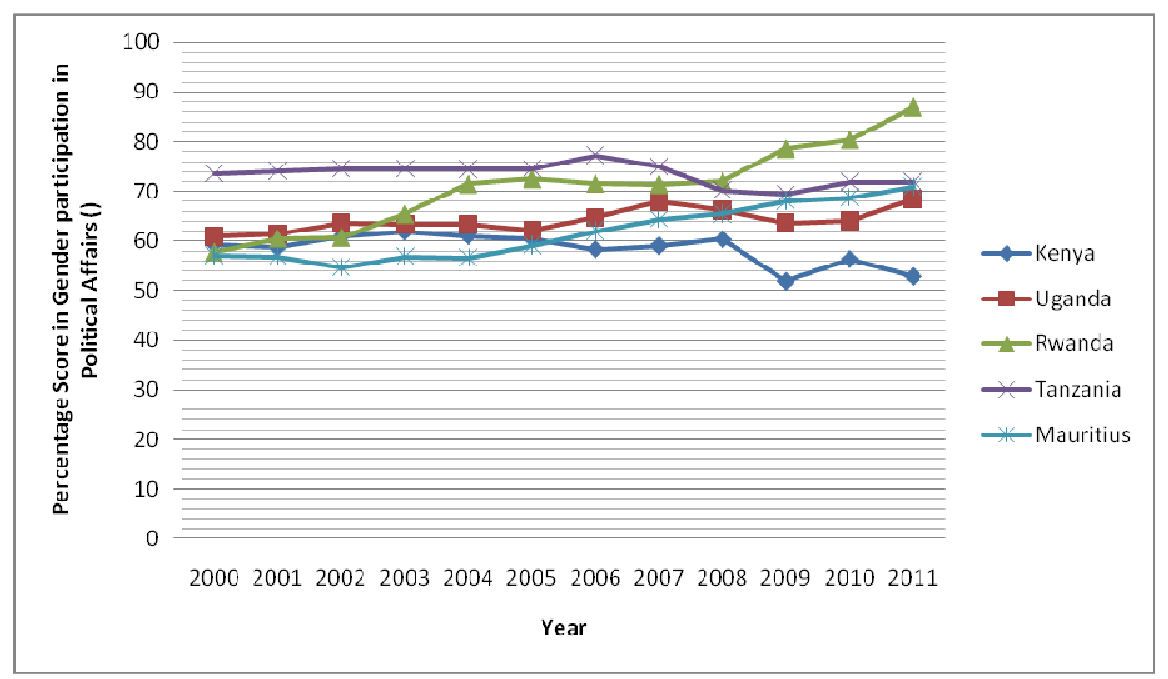

Source: Compiled by author from MoIbrahim (2012)

Figure 2. Gender Participation in Political Affairs in Eastern Africa 2000-2011 
In 2006 Kenya's performance score in overall participation was $66.2 \%$ which has been dropping and in 2011 the score was $49.5 \%$ having declined drastically by $-16.7 \%$ percentage points (Figure 1). It is worth noting representative democracy does not guarantee that the concerns of women and those affected by historical discrimination will be addressed. As such, participation needs to be informed and organized, and needs to be predicated on freedom of and capacity for association and expression. Citizen participation is meant to increase democracy and good governance, citizen empowerment and operational modalities of citizen involvement in public affairs. Kenya is also below other countries in the East African region in gender participation political affairs as seen in Figure 2 above.

Kenya still lags behind when it comes to equal gender participation in governance with a percentage score of $52.9 \%$ in 2011, compared to Rwanda which had a percentage score of $87.0 \%$. Among the other East African countries, Uganda scored $68.5 \%$, Tanzania had $71.9 \%$ whereas Mauritius had a score of $71.0 \%$. It should also be noted that in 2011, Rwanda's score in women representation in Parliament stood above $80 \%$. These gains made by women in Rwanda came about as a result of good political will from the country's political leadership that put emphasis on gender equity and equality.

Even though the constitution requires that no gender holds more than two thirds of political appointments, public offices and other civil service positions, this is yet to be actualized in the selected Kenyan civil service dockets as seen the table 1 below:

Table 1. Proportions of Women in Political and Major Government Institutions, 2012

\begin{tabular}{|c|c|c|c|c|}
\hline Rank/Position & Men & Women & Total & \% of women \\
\hline Ministers & 34 & 6 & 40 & 15.0 \\
\hline Assistant Ministers & 41 & 5 & 46 & 10.9 \\
\hline National Assembly & 200 & 22 & 222 & 9.9 \\
\hline Ambassadors/High Commissioners & 40 & 8 & 48 & 16.7 \\
\hline Permanent Secretaries & 38 & 6 & 44 & 13.6 \\
\hline Secretaries & 20 & 2 & 22 & 9.1 \\
\hline Deputy Secretaries & 77 & 21 & 98 & 21.4 \\
\hline Deputy Provincial Commissioners & 19 & 2 & 21 & 9.5 \\
\hline District Commissioners & 201 & 18 & 219 & 8.2 \\
\hline Councillors & 2322 & 112 & 2434 & 4.6 \\
\hline District Officers & 730 & 210 & 940 & 22.3 \\
\hline Kadhis & 18 & 0 & 18 & 100 \\
\hline
\end{tabular}

Source: Directorate of Personnel Management, Cabinet Office, Public Service Commission and author

As seen in (Table 1) women are still underrepresented in Public Service jobs. It is only amongst ranks of District Officers and Deputy Secretaries where the gender gap is almost being bridged since it is above $20 \%$ in these two positions. Lack of political will and commitment on the part of political leaders and government is the biggest impediment so far. Gender equity is most of the time implemented through the will and desires of the political ruling class as if there are no legal binding frameworks.
Thus much effort need to be put in place to ensure that political parties and other political actors and all institutions of governance adhere to the constitution to ensure that the historical marginalization of women is addressed. The findings above (Table 1) are similar to findings by Afrobarometer round 5 which found out that over $33 \%$ of Kenyans (Figure 3) believe that women are treated unequally by employers in favor of men.

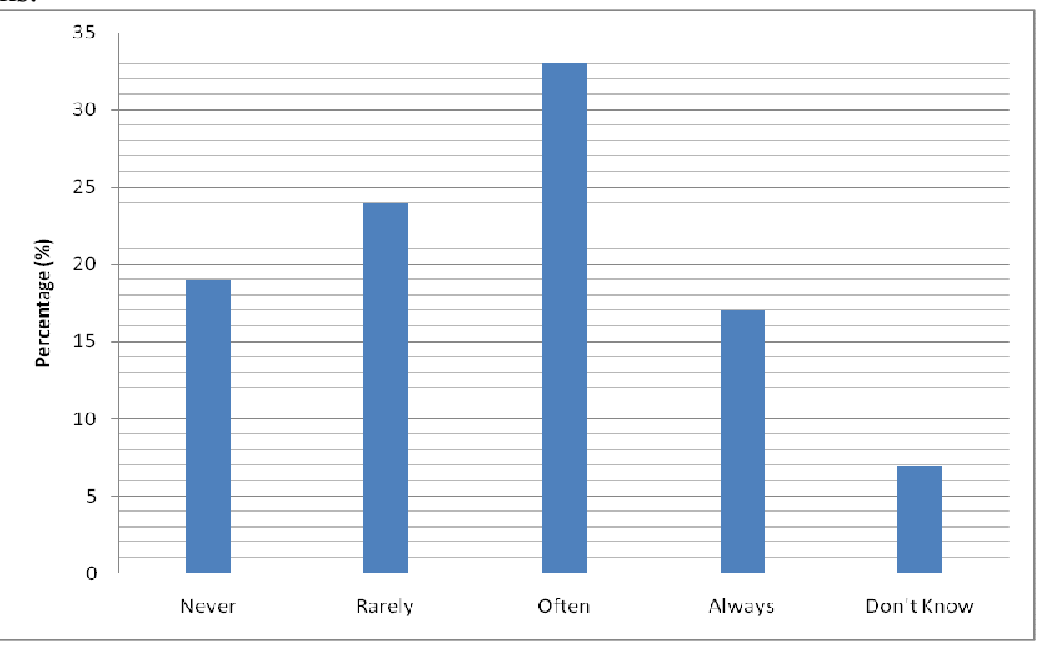

Source: Afrobarometer (2012)

Figure 3. How Often Women are treated Unequally during employment by employers in favour of men 
This discrimination of women during employment further militates against gender mainstreaming since with no form of employment women are further disadvantaged economically.

There are many obstacles that hinder the participation of women in political governance and decision making in Kenya. In the discussion that follows, these obstacles have been addressed in three broad categories namely: cultural, economic and political.

\subsection{Cultural Barriers}

Many African communities' customs tend to negate the role of women in mainstream political leadership regarding them only as home makers thus restricting them to those roles. Cultural factors are linked to stereotype beliefs about the ability and capacity of women across many communities. Also connected to cultural factors is the patriarchal ideology which provides the context upon which women play and accept subsidiary roles. Sex stereo-types (Refer to table 2 below) are among the most firmly entrenched obstacles to the elimination of discrimination thus largely responsible for undermining gender equity (United Nations 2000). These cultural perceptions do not encourage women at all to actively participate in politics. In most religions power and authority is believed to divinely belong to men hence subjugating women. Thus women are encouraged to play subsidiary roles since their place is in the kitchen and men are the decision makers.
In most African communities, women are not allowed to address men in public because it is considered taboo to do so. In fact most women still believe that their marital status in a home can only be cemented when they give birth to a male child. This tends to have a psychological effect and hence relegating women to subservient roles in development matters in the community.

Traditional inheritance laws in Kenya tend to favor men. Property and resources in the family are controlled and shared out by men. Women rarely inherit property from their parents.

This puts women in a disadvantageous position economically. In communities still practicing retrogressive practices like Female Genital Mutilation (FGM), forced and/or early/planned marriages, women who have not undergone this rite of passage (FGM) are regarded to be "children" and thus cannot be allowed to run for any elective position. Among pastoral communities life is structured along clan lines which are controlled by a council of elders. These councils are the ones that select who to run for political offices. These councils of elders are often reluctant to endorse or support female candidates. This then locks out potential female candidates who may have better leadership skills and abilities. It is worth noting that over $30 \%$ of Kenyans believe that women are often treated unequally by traditional leaders by virtue of them being considered the weaker sex (Figure 4)

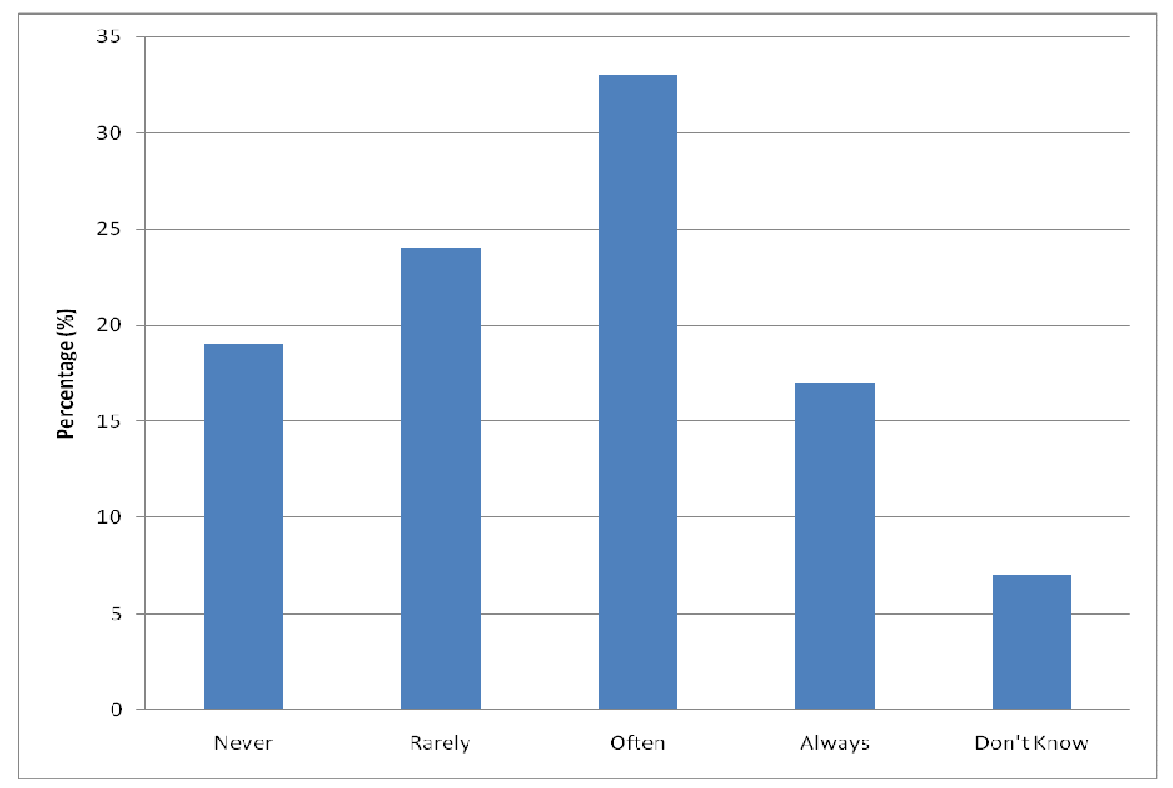

Source: Afrobarometer(2012)

Figure 4. How Often Women are Treated Unequally by Traditional Leaders

The electorate is thus reluctant to support them because of this retrogressive belief. In a number of Kenyan communities, single and divorced women cannot be allowed to run for political office and those who do are ridiculed and insulted in public meetings. This is so because societal norms and socialization tends to be harsh on women. Men who are divorced are never treated with contempt the way women are.
This can be traced to the patriarchal nature of most communities in this country. According to Chafetz and Dworkin (1986) women have had to contend and contest established beliefs that politics is a domain of main only. Stereotypes about women can affect women's levels of representation throughout the political process, from an individual woman's decision to enter politics, to party 
selection of candidates to the actual voting patterns by the electorate. Religion is another source of anachronistic cultural beliefs in many communities in the country that excludes women from mainstream leadership. Arguments about women's inferiority to men are present across all dominant religions, and traditionally religion has long been used to exclude women from aspects of social, political, or religious life around the world (Paxton and Hughes 2007).

Women also seem to be their own enemies in their own political advancement and empowerment, especially when they internalize these long held anachronistic assumptions and perceptions that politics is a dirty game thus a preserve game of men. Long held Communal stereotypes against women have tended to militate against gender equality and women empowerment. For instance, women who are politically active are labeled as "irresponsible" and therefore not fit to be "wife material" since they are "loose". For instance, men across most African communities are socialized to be aggressive, brave, autocrat, dominant and independent whereas women are labeled as emotional, sentimental and fragile. Stereotypes are most of the time negative and have been used to marginalize women in leadership and decision making organs. Some of the commonly held stereotypes on both genders as shown in the table 2 below:

Table 2. Commonly Held Gender Stereotypes in Kenya

\begin{tabular}{lll}
\hline Ability & Female Stereotypes & Male Stereotypes \\
\hline \multirow{2}{*}{ Emotions } & Gentle, Soft hearted, sensitive, emotional, Sentimental, Fearful, Cry-babies, Cannot & Stable, Never cry, Brave, Aggressive, Can hold \\
& hold emotion, & emotion \\
Attitude & Dependent, Submissive, Superstitious, Irresponsible, Talk too much, Submissiveness & Assertive, Responsible, Courageous, \\
Biology & Weak, Frail, dainty and charming & Powerful, energetic, strong and never get tired \\
Intelligence & Dreamy, less capable & Intelligent, Wise, logical \\
\hline
\end{tabular}

Source: Compiled by author

Gender stereotypes are formed over a long period of time as a result of cultural beliefs, practices and traditions. Within time they are taken to be "true" since people internalize them and make them to appear like inherent within people and society at large. If the society is patriarchal like is the case in many Kenyan communities, then most positive attributes will be attached to males. African traditions have mainly defined and ascribed separate roles to males and females. While the male roles are more empowering, the female roles seem to be disempowering. These gender roles and societal expectations hinder the participation of women in politics. Most of our communities are patriarchal in nature. Men remain at the helm of affairs and make decisions virtually exclusively, even when the issues border on women matters. The few women who venture into "the man's world" feel inhibited to speak, especially when they are in large, male-dominated assemblies. Those who muster up enough courage and strength to speak receive very scant attention and respect.

Many patriarchal communities in Kenya do not see the need for gender parity since most of them are patriarchal in nature and often see gender equality as a challenge to male dominance and hegemony. Most of the time women are ridiculed through songs and proverbs As long as our socialization still favors men, it will be difficult for women to participate on equal footing with men in political competition. Since independence the Kenyan government has not put forth any initiatives to identify negative gender stereotypes and prescribe measures to address them. In as much as proverbs, idioms and wise sayings had their function in the respective communities, some have been taken to the extreme thus alienating women from leadership.

\subsection{Economic Barriers}

Socio-economic status of women to a greater extent play a significant role in enhancing their participation and representation in political decision making bodies. Thus access to means of production and finances has a direct relationship and influence on the participation of women in political institutions and electoral bodies like the Senate, National assembly and County Assemblies. In most Kenyan communities women have no access to land and property rights though they are guaranteed in the constitution. This economically incapacitates them hence they cannot vie and run successful political campaigns where campaigns are highly expensive. Therefore this discrimination of access of women to means of production especially land and property rights severely contributes to this low level of their active participation in politics and governance. While highlighting many areas of women's disadvantage, Wanjala and Odongo (2010) note that women constitute a mere $23 \%$ of members of Kenyan cooperative societies, which are known to provide easier access to credit. This has in essence further marginalized women in economic empowerment.

According to Afifu (2008) poverty facing women in rural communities is their biggest hurdle in their quest to venture into elective politics. According to Census Report, (2009) there is a huge economic gap between urban and rural communities in Kenya. Kenya's rural population is $63 \%$ whereas the urban population stands at $37 \%$ (Ibid).Also majority of women live in rural areas and their access to economic resources is limited compared to their urban counterparts. This makes it difficult for them to compete on equal footing with men in national or even regional elective politics. Thus economic empowerment of women reinforced by education and access to information may guarantee women full participation in elective politics.

Economic empowerment of women results into ownership of resources: Resources especially finance is critical in electoral processes for during organization of campaign meetings, publicity and payment of nomination fees to nominating political parties and to the Independent Electoral and Boundaries Commission (IEBC). When women are 
politically empowered they are in a better position to influence key policy decisions in the Executive and Legislative arm of government. The economic empowerment of women, along with education and access to information, will take women from the constraints of the household to full participation in politics and political elections.

\subsection{Political Barriers}

Political structures can play a significant role in women's recruitment to parliament. Among the political obstacles that women face, the following feature prominently:

- Politics in Kenya has always been associated with masculinity thus "a men only affair"

- Most political parties are dominated by men thus making it difficult for women to have political networks for mobilization

- Most public organizations like Labor unions are also dominated by men

- Women in Kenya have never been oriented towards politics and their training is not tailored towards political leadership representation

- Our electoral politics is prone to violence most of the times thus scaring away most women

- Electoral related violence is also another impediment that hinders the participation of female candidates. Since in most African communities women are considered a "weaker gender", they more often than not potential targets where political thugs and hired goons target them. Male candidates are more likely than female candidates to introduce political violence and hooliganism in their campaigns. Brazen attacks on female candidates and their families often intimidate them and make many aspiring female candidates to shun politics all together. According to Mittulah and Owiti (2011) lack of political goodwill by their male politicians to include women in structures of political governance is to blame for limited participation in political parties. When women's needs are ignored it results in high infant and child mortality, unaccountable population growth, poor economic growth, Low agricultural yields and this directly impacts on the quality of life of citizens women being the most affected (Abidi 192).Thus involvement of women in decision making is a big step towards reducing poverty and reducing huge income inequalities between men and women.

\section{Conclusion}

The demography of Kenya is an indicator that women must be involved in active key decision making bodies especially given the fact that we have a devolved system of governance. Going by the March 2013 elections, women are still underrepresented in political leadership roles. For example, there was no single female Governor elected in the 47 counties, there was no single female senator elected and out of 1450 county wards women only managed to get elected in 88 wards. This is a big setback for devolution and hence an indicator that women will still be marginalized in county governments as has been the case in the former centralized governance structures. This shows that women are still only being used as "voting machines" and providing political support to male candidates as has been the case since independence. Thus there is greater need to have gender parity in political power and decision making organs in county governments to ensure that the marginalization of women that has been there in the past does not replicate itself in our counties.

\section{Strategy Recommendations}

- Political parties ought to develop internal democratic structures and mechanisms to ensure that they encourage and have more female candidates on the ballot. Political party laws and legislation related to election should not directly or indirectly disadvantage women participation. For example, nomination fees for women candidates should be reduced so as to encourage more female candidates' participation in party primaries. Party advocacy, activism, training and internal democracy of political parties in Kenya is key to increasing women's political participation. Civic education should focus on enlightening communities on the right of women to vie for electoral positions, be elected and to vote minus any form of meddling or interference either from husbands, elders or any other person. Political parties should be the first institution to promote gender equity in electoral participation.

- The Independent Electoral and Boundaries Commission (IEBC) must hold political parties accountable to law to practice internal democracy by instituting affirmative action to support the historically marginalized groups such as women in decision making bodies within the same parties. International commitments, such as the Millennium Development Goals which have been entrenched in our national policies and goals frameworks must be actualized. The right of access of women to political participation and decision making needs to be seriously emphasized.

- Long held retrogressive stereotypical gender roles in public life can be undermined through civic education and extensive campaigns to create public awareness so as to achieve equal gender political representation in Kenya.

- In the view of this study if political parties adhere to the one third minimum constitutional requirement for their party candidate lists, this may boost and increase the electability of women. This is one of the frameworks that need to be pursued by the government and political parties. There is need for a law to be enacted that makes it mandatory and prescribe penalties for parties that fail to observe the one third constitutional gender requirement within their file and rank of all candidates nominated by a party to contest political seats.

- Establishment of entrepreneurship skills training in business management for women: This will help 
concentrate on providing the necessary skills needed for growing women's capacity in starting and managing businesses.

\section{References}

[1] Abidi S. (1991) The role of religious organisations in development of Uganda. Kampala: Foundation for African Development

[2] Afifu, T. (2008) Party clearance: Women in Kenya politics. Nairobi: Women's Shadow Parliament-Kenya

[3] Bem, S. L. (1981) Gender schema theory: A cognitive account of sex typing. Psychological Review, 88, 354-364

[4] Carrol S. (1994) Women as candidates in American politics. Bloomington: Indiana University Press

[5] Chafetz J.S and Dworkin A.G. (1986). Female revolt: women's movements in world and historical perspective. Totowa, NJ: Rowman and Allanheld

[6] Cooper C. (1982) High pressure: Working lives of women managers. London: Fontana Cornwall, Andrea and Goetz, Anne Marie (2005)"Democratizing Democracy: Feminist perspectives $^{\text {ee }}$, Democratization, 12 (5): 783 - 800

[7] Devlin, C and Elgie, R. (2008) The effect of increased women's representation in parliament: The case of Rwanda. Parliamentary Affairs, 61 (2) pp. 237-254. Available at SSRN: http://ssrn.com

[8] Eisenstein Z. (1984) Contemporary feminist thought. London: Unwin

[9] Huggins, A. and Randell, Shirley K. (2007) Gender equality in education in Rwanda: What is happening to our girls? A Paper presented at the South African Association of Women Graduates Conference on "Drop-outs from School and Tertiary Studies: What is Happening to our Girls?" Cape Town, May, 2007

[10] IDEA, Inter-Parliamentary Union and Stockholm University (2010) Global database of electoral quotas for women. www.quotaproject.org

[11] Institute of Economic Affairs - IEA (2007) Gender budgeting and cdf: A gender benefit incidence analysis of four constituencies. Nairobi: Institute of Economic Affairs.

[12] Igwee O (2002) Politics and globe dictionary. Enugu: Jamoe Enterprises .

[13] Karl M. (2001) Women and empowerment: participation and decision making. London: Zed Books Ltd
[14] Kenya, Republic of. (2010b) The constitution of Kenya. Nairobi: Government Printer.

[15] Kenya, Republic of. (2011) The political parties act. Nairobi: Government Printer.

[16] Lijphart, A. (1997). Unequal participation: Democracy's unresolved dilemma. The American Political Science Review, $91,1-14$

[17] Mitullah, W. and Owiti L. (2007) Women and the politics of transition In Peter Wanyande, Mary 18 Omosa and Chweya Ludeki (eds), governance and transition politics in Kenya. Nairobi: University of Nairobi Press. pp. $155-178$.

[18] Nyanjom O. (2011) Devolution in Kenyans' new constitution. Constitution working paper series no. 4. Nairobi: Society for International Development.

[19] Nzomo, M. and Kibwana, K. (2003) Women and politics in Kenya. Nairobi: East African Education Publishers

[20] Okello, R. (2010) Beyond numbers: Narrating the impact of women's leadership in eastern Africa. Nairobi: African Woman and Child Feature Services

[21] Oduol J. A. (2011) Woman in leadership and governance In Okoth Okombo et al., (Eds) Challenging the rulers: A leadership model for good governance. Nairobi: EAEP and Community Aid International.

[22] Ouma H. and Maina B.N. (2010) Vision 2030, social pillar gender analysis.In Society for International Development (2010), p. 72-138.

[23] Paxton, P., Kunovich, S. and Hughes, M.M. (2007) Gender in politics. Annual Review of Sociology, 33, 263-284.

[24] Paxton P. and Hughes M.M. (2007) Women, politics, and power: A global perspective. Thousand Oaks, CA: Pine Forge

[25] Republic of Kenya (2011) The political parties act. Nairobi: Government Printer.

[26] Republic of Kenya (2007) Gender mainstreaming implementation plan of action for the national policy on gender and development. Nairobi: Government Printer.

[27] Thomas, S. (1994) How women legislate. Oxford: Oxford University Press.

[28] Tremblay, M. (1998) Do female mps substantively represent women?: A study of legislative behaviour in Canada's 35th parliament. Canadian Journal of Political Science 31. 435-466.

[29] Wanjala B.M and Odongo M.T. (2010) Gender and Kenya vision 2030: An audit of the economic pillar. In Society for International Development (2010), p 41-69. 